\title{
Epithelioid Haemangioma of Bone: A Case Series and Comprehensive Literature Review Reappraising the Diagnostic Classification of All Epithelioid Vascular Neoplasms of Bone
}

\author{
Subramaniam Ramkumar ${ }^{1}$ \\ 1. Pathology, Woodland Hospital, Shillong, IND \\ Corresponding author: Subramaniam Ramkumar, drramkumar@woodlandpathology.com
}

\begin{abstract}
Epithelioid vascular neoplasms of the bone are classified by the World Health Organization (WHO) into only two tiers: low-grade epithelioid hemangioma (EH) and a more malignant category including both epithelioid hemangioendothelioma and epithelioid angiosarcoma. The World Health Organization defines bone EH as a locally aggressive neoplasm with no connotation of benign or intermediate malignancy. We reviewed three cases of EH in our lab archives with the perspective of appraising their histomorphological approach toward diagnosis. Patients were in the age range of 15-25 years. The site of the neoplasms ranged from the carpal bones to the metatarsal bones. Histomorphological examination of the lesions showed a nodular growth pattern of a vascular neoplasm without demonstrable vessel origin. The vasoformative area increased from the center to the periphery, with prominent epithelioid morphology of the endothelial cells at the periphery and an associated inflammatory infiltrate comprising eosinophils, lymphocytes, and plasma cells. The growth pattern was diffuse, with extension into the deeper dermis of overlying skin.
\end{abstract}

Review began 05/21/2021 Review ended 05/25/2021 Published 06/01/2021

๑) Copyright 2021 Ramkumar. This is an open access article distributed under the terms of the Creative Commons Attribution License CC-BY 4.0., which permits unrestricted use, distribution, and reproduction in any medium, provided the original author and source are credited.
Categories: Pathology, Oncology, Orthopedics

Keywords: epithelioid, bone neoplasms, vascular neoplasms, pseudomyogenic haemangioendothelioma, bone, epithelioid haemangioma, epithelioid haemangioendothelioma, epithelioid angiosarcoma, fos gene, wwtr1-camta1

\section{Introduction}

Vascular tumors encompass a wide histologic spectrum, including hemangioma, hemangioendothelioma, angiosarcoma, and respective epithelioid variants. The World Health Organization (WHO) classified softtissue epithelioid vascular tumors into three distinct entities based on malignancy level: benign epithelioid hemangioma (EH) [1], intermediate-grade epithelioid hemangioendothelioma (EHE) [1], and malignant epithelioid angiosarcoma (EAS). However, the same edition of WHO classifies bone epithelioid vascular tumors into only two levels: EH and a more malignant category including both EHE and EAS [1]. This revised classification of bone epithelioid vascular lesions is likely owing to reported EH cases with recurrence and lymph node involvement. The intermediate category of classifying soft-tissue epithelioid vascular neoplasms is defined by an infiltrative and locally destructive growth pattern, often recurring and occasionally $(<2 \%)$ metastasizing [1]. If these criteria are applied to $\mathrm{EH}$ of bone, recurring in $11 \%$ and metastasizing in $2.7 \%$, this entity fits best within this intermediate category, in between benign and angiosarcoma (malignant) of bone [2]. However, WHO defines bone EH as a locally aggressive neoplasm with no connotation of benign or intermediate malignancy. Therefore, EH continues to be confused with and erroneously misclassified as EHE or some other vascular sarcoma type. This terminology and classification have proven particularly controversial for intraosseous epithelioid vascular tumors at the low end of the malignancy spectrum [3-4]. Here, we describe the clinical and histomorphological features of three cases with osteolytic lesions in the limb extremities and re-evaluate the criteria for distinguishing $\mathrm{EH}$ from similar reactive and neoplastic epithelioid vascular lesions based on previous studies.

\section{Case Presentation}

Bone curettage specimens from three patients with bone EH were retrospectively analyzed.

EH diagnosis was established based on hematoxylin and eosin (H\&E) and immunohistochemical (IHC) staining of paraffin-embedded tissue sections. In each biopsy specimen, overall architecture (lobular or diffuse), the extent of vascular proliferation (focal or diffuse), and the presence of epithelioid endothelial cells were evaluated. Furthermore, the characteristic features of the dermal inflammatory infiltrate were assessed, including distribution (perivascular, band-like, periadnexal, or diffuse), depth (papillary dermis, reticular dermis, or subcutis), predominant cell type (lymphocytes, eosinophils, or plasma cells), and presence/absence of germinal centers. All specimens were immunohistochemically stained using the threestep indirect peroxidase complex technique after a preliminary automated pressure-based antigen retrieval step. Diaminobenzidine was then applied as the chromogen. All specimens were stained with anti-Ki-67, anti-CD34, anti-CD45, anti-CD19, anti-CD20, anti-PAN-CK, anti-Cd1A, anti-desmin (D33) (1:320, 


\section{Cureus}

Pathnsitu), anti-smooth muscle actin (anti-SMA, 1:160, Pathnsitu), anti-keratin cocktail (AE1/AE3, 1:1280 Pathnsitu), anti-factor VIIIrAg (1:5120, Dako), anti-CD31(1:80, Dako), and anti-CD34 [1:640, $\mathrm{m}(\mathrm{QBEnd} / 10)$,Dako] monoclonal antibodies.

The first patient in the case series was a 15 -year-old male. He presented in the casualty with a slowly growing swelling in the forefoot for two years. The X-ray revealed an ill-defined osteolytic lesion in the second metatarsal bone with expansile margins. A provisional diagnosis of enchondroma was made. The patient was treated with bone curettage. Microscopy revealed an irregular infiltrative vascular neoplasm with a nodular/lobular growth pattern without any demonstrable vessel origin (Figure 1).

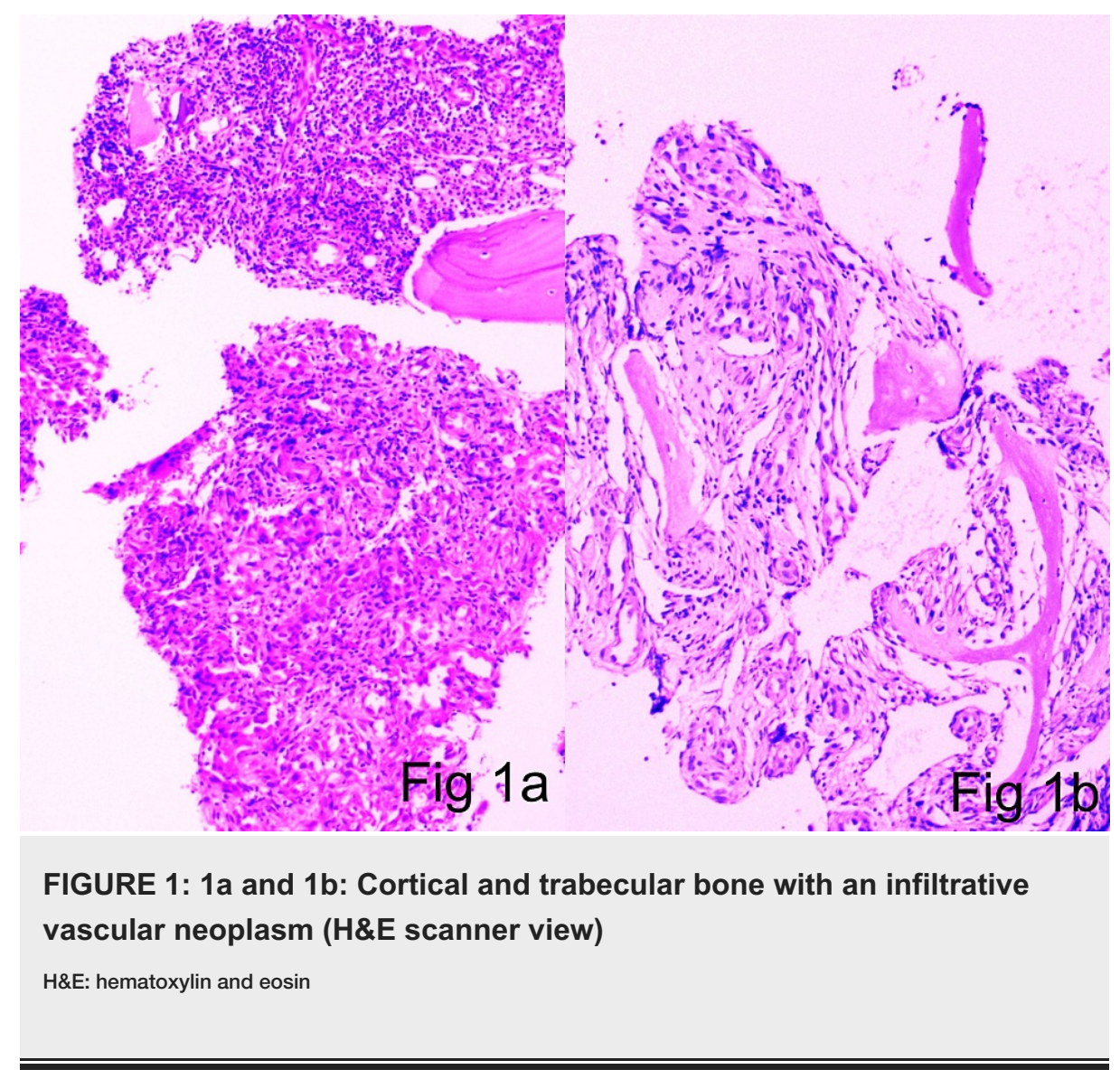

The pattern of growth in the central zone was diffuse in sheets. Focal spindling of cells arranged in fascicles with slit-like vasculature was noted (Figure 2). Peripherally, the pattern of growth showed well-formed vascular channels with prominent epithelioid endothelial cell morphology and hobnailing. 


\section{Cureus}

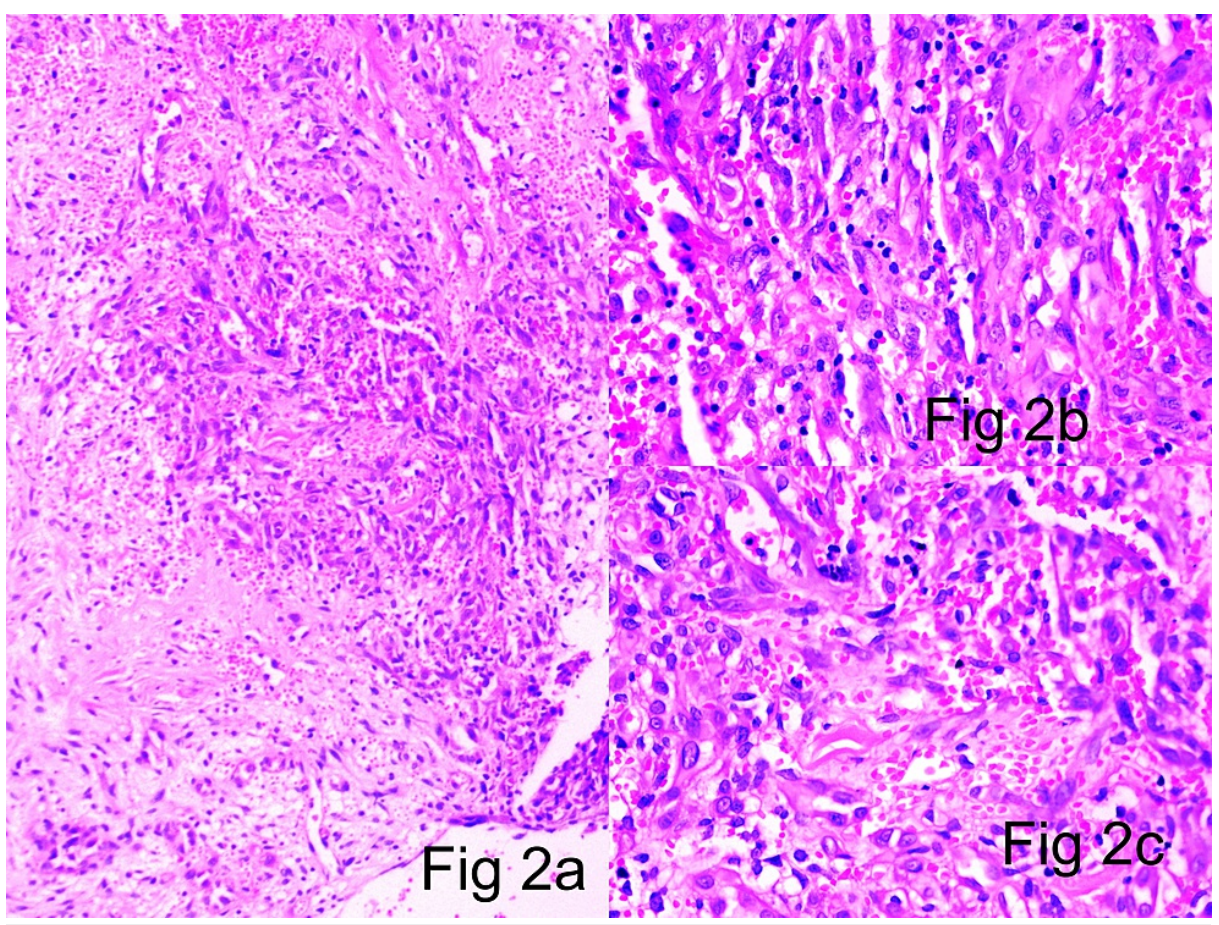

FIGURE 2: 2a (H\&E x10), 2b (H\&E x40), 2c (H\&E x40): Central solid areas composed of endothelial cell sheets with interspersed slit-like channels

H\&E: hematoxylin and eosin

The tumor-associated stroma showed sheets of eosinophils, along with lymphocytes, extravasated red blood cells (RBCs), and plasma cells. Lymphoid aggregates were seen but were negative for germinal centers. The growth pattern was diffuse and extending into the deep dermis of the overlying skin. A diagnosis of EH involving the second metatarsal bone was made. There was no recurrence on follow-up. The patient was declared cured, and no subsequent treatment was given on follow-up.

The second patient in the case series was a 25 -year-old female. The patient presented in the OPD with an insidious onset and progressive swelling in the wrist. X-ray showed an ill-defined osteolytic lesion involving the carpal bones. The lesion also showed cortical erosion and periosteal reactive bone formation. A clinical provisional diagnosis of an aneurysmal bone cyst was made. The patient was treated with bone curettage. Microscopy showed a nodular/lobular growth pattern of a vascular neoplasm without any demonstrable vessel origin. The central growth pattern was in diffuse sheets. Focal spindling of the cells was noted, which were arranged in fascicles with slit-like vascularity. Peripheral well-formed blood vessels were seen with epithelioid endothelial cells showing prominent hobnailing (Figure 3). 


\section{Cureus}

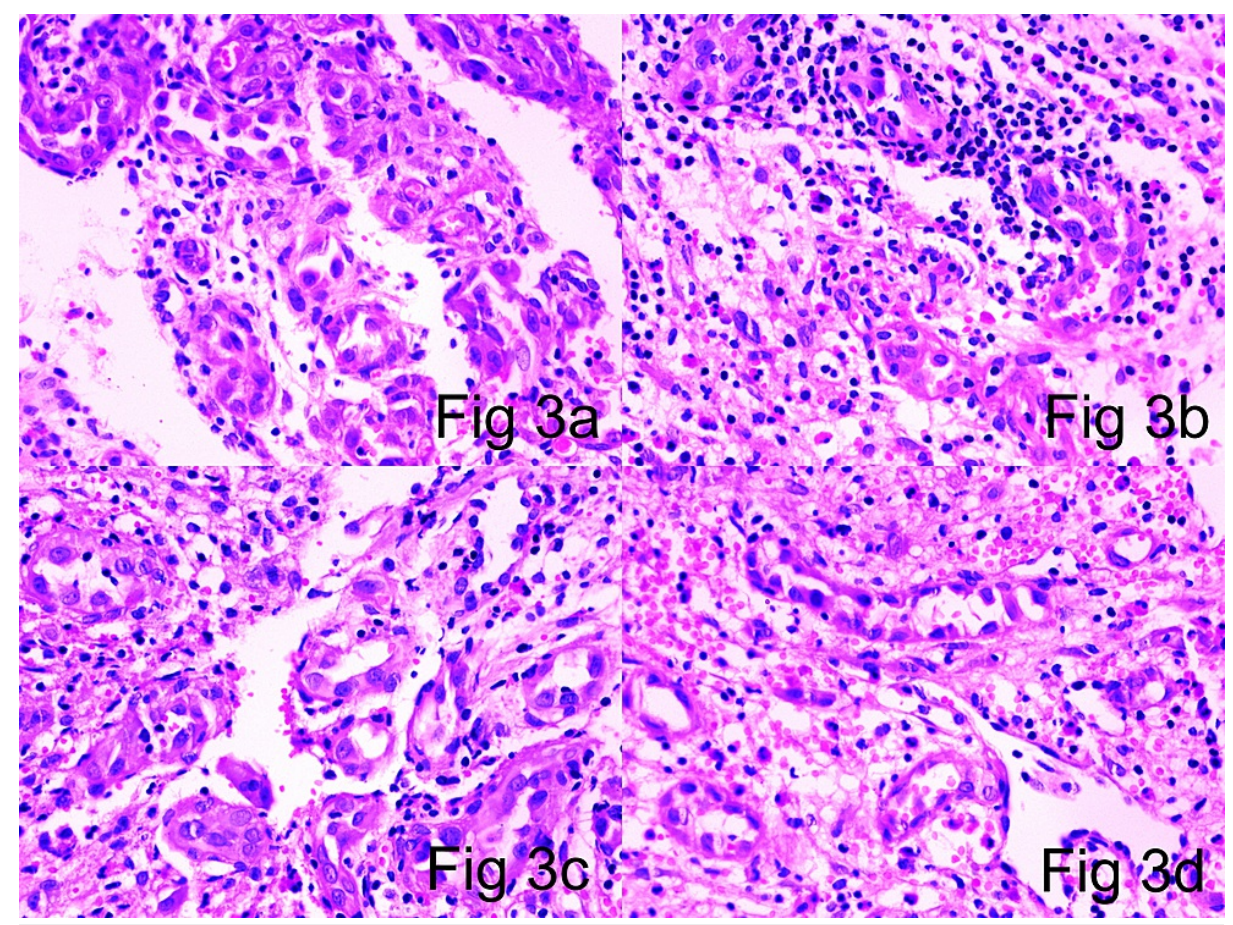

FIGURE 3: 3a (H\&E x10), 3b (H\&E x10), 3c (H\&E x10), 3d (H\&E x10):

Peripheral well-defined vasformative areas showing large vessels with plump hobnailed endothelial cells and epithelioid endothelial cells

H\&E: hematoxylin and eosin

The tumor-associated stroma showed sheets of eosinophils, eosinophilic microabscesses, along with lymphocytes and plasma cells. Focal lymphoid aggregates were seen but were negative for germinal centers (Figure 4). 


\section{Cureus}

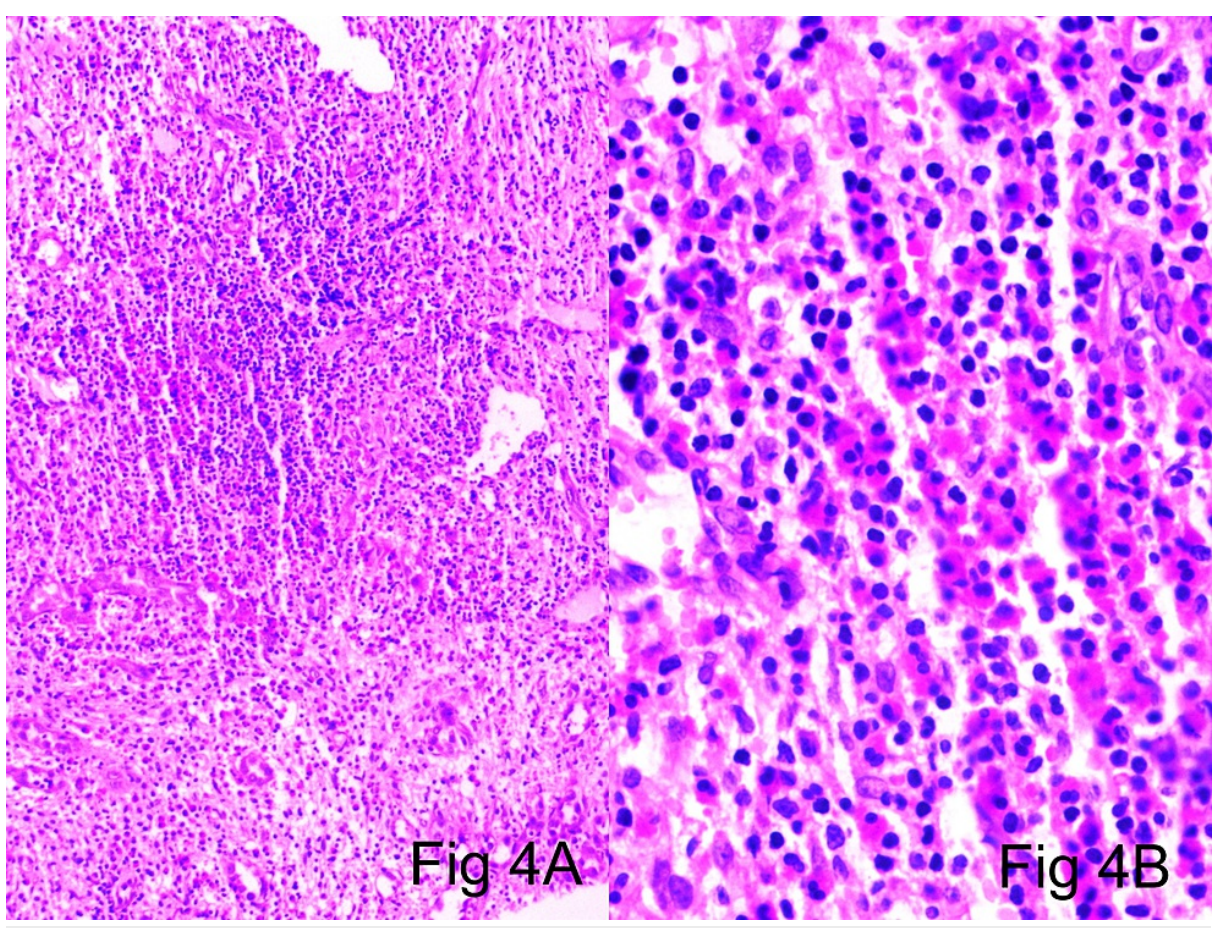

FIGURE 4: 4a (H\&E scanner), 4b (H\&E x40): Tumor-associated stroma showing sheets of eosinophils along with lymphocytes and plasma cells

H\&E: hematoxylin and eosin

There was focal spindling of cells arranged in fascicles with slit-like vasculature. A diagnosis of EH involving the carpal bones was made. There was no recurrence on follow-up. The patient was declared cured and no subsequent treatment was given on follow-up.

The third patient in the case series was a 20 -year-old male. The patient presented with an osteolytic lesion in the first metatarsal bone. The patient presented in the casualty with a progressive slowly growing mass, which was insidious in onset. Radiologically, the lesion was ill-defined, expansile, with sclerotic margins and reactive bone formation. A clinical provisional diagnosis of enchondroma was made. The patient was treated with bone curettage. Microscopy showed a nodular growth pattern without any demonstrable vessel origin. The central growth pattern was diffuse in sheets with peripheral, well-formed channels. The vessels showed prominent epithelioid endothelial cells with hobnailing. The tumor-associated inflammatory stroma showed sheets of eosinophils along with lymphocytes and plasma cells. The growth pattern was diffuse and extending into the deeper dermis of the overlying skin. The epithelioid endothelial cells were immunoreactive for cluster of differentiation 31 (CD31), CD34, factor VIIIrAg, and pan-cytokeratin (PANCK). Smooth muscle actin, desmin, and muscle-specific actin (HHF-35) (Figure 5) were expressed in all cases and highlighted a population of myopericytic cells intimately associated with epithelioid endothelial cells. The cells were negative for CD1a, langerin, and CD86. 


\section{Cureus}

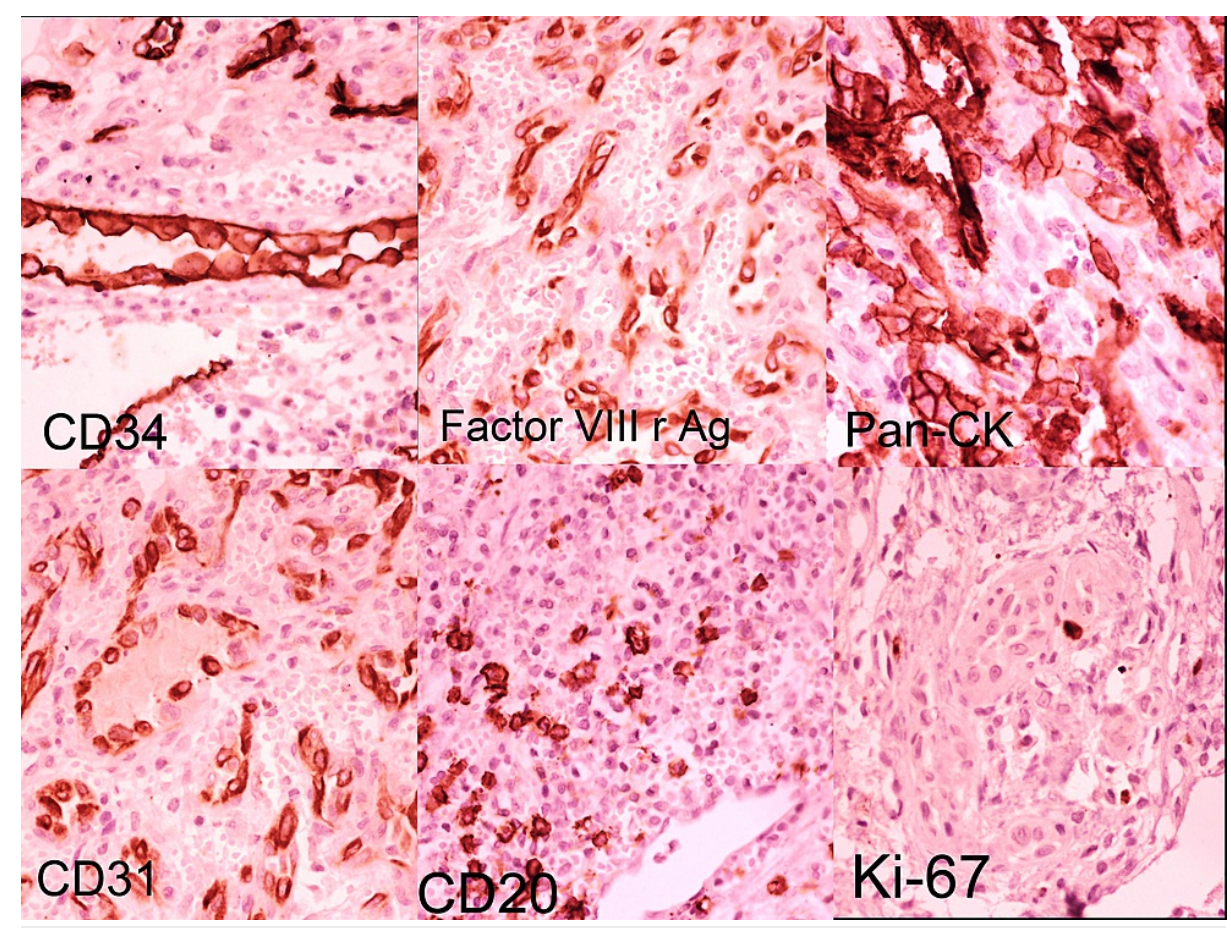

FIGURE 5: Tumor-associated epithelioid endothelial cells showing immunohistochemical positivity for CD34, Factor VIIIr and Ag, PAN-CK, as well as a low $\mathrm{Ki}-67$ mitotic index

CD: cluster of differentiation; PAN-CK: pan-cytokeratin

A diagnosis of EH involving the first metatarsal bone was made. There was no recurrence on follow-up. The patient was declared cured and no subsequent treatment was given on follow-up.

The clinical characteristics, including the patients' demographics, lesions, treatment, and follow-up, are summarized in Table 1 . 


\section{Cureus}

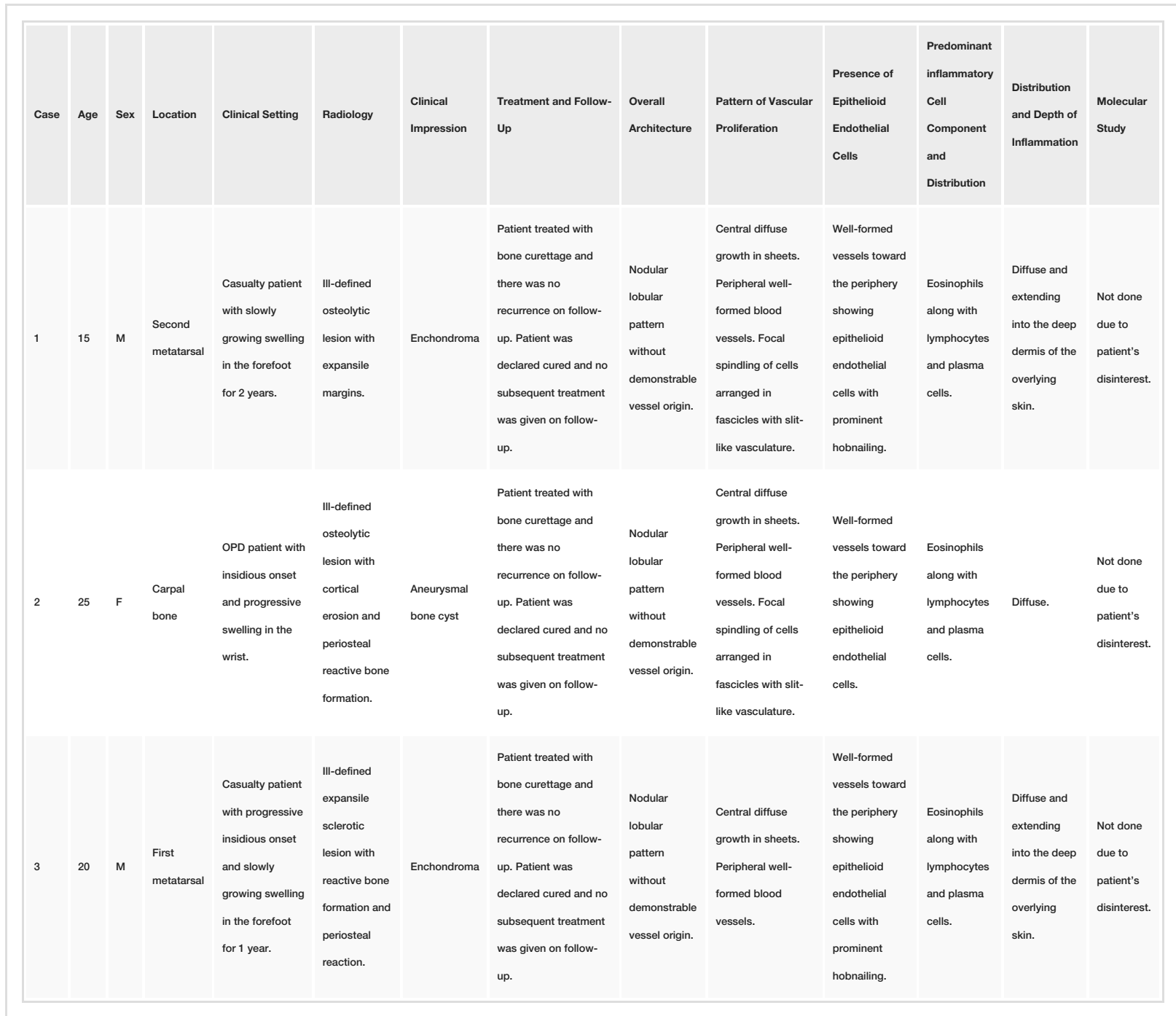

TABLE 1: Histopathological features of three bone epithelioid hemangioma cases

OPD: outpatient department

\section{Pathological features of the case series}

Microscopic examination of tumor specimens revealed an ill-defined lobular contour and no visible symmetrical arterial/parent feeder vessel association in all three cases. The vascular components exhibited central exuberant solid sheets of endothelial cells interspersed by slit-like channels containing red blood cells, with well-defined vessels in the lesion periphery compared with that in the central zone (Figure 1a-1b, Figure $2 a-2 b$ ). Larger blood vessels were lined by well-defined epithelioid endothelial cells showing hob nailing within foci (Figure 3). Mitotic figures were extremely infrequent, with only 1-5 mitoses/10 highpowered field (hpf). The stroma was densely fibrocollagenous, showing eosinophils sheets along with lymphocytes and plasma cells (Figure 4).

There was no prominent germinal center formation in any sample. The epithelioid endothelial cells were immunoreactive for CD31, CD34, and factor VIIIrAg. Smooth muscle actin, desmin, and muscle-specific actin (HHF-35) (Figure 5) were expressed in all cases and highlighted a population of myopericytic cells intimately associated with epithelioid endothelial cells. The cells were negative for CD1a, langerin, and CD86. All lesions lacked extensive mitotic activity, atypical mitotic figures, and nuclear atypia. There was no prominent germinal center formation in any sample. The epithelioid endothelial cells were immunoreactive for CD31, CD34, and factor VIIIrAg. Smooth muscle actin, desmin, and muscle-specific actin (HHF-35) (Figure 5) were expressed in all cases and highlighted a population of myopericytic cells intimately associated with epithelioid endothelial cells. The cells were negative for CD1a, langerin, and CD86. All lesions lacked extensive mitotic activity, atypical mitotic figures, and nuclear atypia.

\section{Discussion}




\section{Historic classification of bone EHs}

Numerous theories on EH tumorigenesis have evolved since its discovery as a distinct pathological entity in the 1960s. EHs are now defined as lesions of distinct endothelial phenotype and epithelioid morphology. Although EH is considered a benign entity, it has metastatic potential. Hartmann and Stewart (1962) provided one of the first detailed descriptions of bone hemangioendothelioma from a case series at Memorial Sloan-Kettering Cancer Center and emphasized its unexpectedly favorable clinical course for malignant vascular tumor [5]. In 1979, Rosai et al. proposed a unifying disease model encompassing several previously described diseases of the skin, soft tissue, large vessels, bone, and heart [6]. The histologic similarity of at least a subset of lower-grade hemangioendothelioma of bone cases to angiolymphoid hyperplasia with eosinophilia (ALHE) suggests that both are representative of a single neoplastic but benign entity subsequently named "histiocytoid hemangioma." Weiss and Enzinger introduced the term soft-tissue EHE to describe a borderline to a low-grade biologically malignant tumor that was histologically similar to but less aggressive than EAS [7]. Although Weiss and Enzinger were doubtful about unifying the lesions included under the umbrella of histiocytoid hemangioma, they concurred that ALHE was neoplastic and suggested the term "epithelioid hemangioma" [7]. Many pathologists accepted Weiss and Enzinger's newly proposed nomenclature; EHEs were subsequently described in multiple other sites, including the bone, lung, and liver [8]. In early review articles, O'Connell et al. [9] and Wenger and Wold [10] proposed classifying vascular neoplasms of the bone along the same lines used for skin and soft-tissue pathologies such as EH, EHE, and EAS. Floris et al. proposed that EH, although usually benign, is a potentially metastasizing lesion; however, the authors stressed that this rare occurrence does not justify upgrading EH into the malignant category [11]. Nonetheless, considering the occasional reported cases of recurrence and lymph node involvement, in the most recent 2020 WHO classification, EH is classified as intermediate grade and EHE and EAS as malignant. Therefore, it is important to accurately distinguish EH from EHE and EAS owing to these critical differences in clinical behavior and prognosis [11].

\section{Occurrence sites}

When EH occurs in osseous tissues, it is most frequently found in the metaphysis and diaphysis of long tubular bones of the extremities, followed by the short tubular bones of the distal lower extremities and flat bones. Males and females aged 30-60 years are equally affected. Patients usually present with insidious onset, slow-growing soft-to-bony swellings, with relevant joint-related movement impairment in the extremities. Occasionally, the clinical presentation can be a pathological fracture that can occur secondary to osteolysis in these lesions. The anatomic distribution of soft-tissue EHs is broad and the most frequently affected sites are the head, particularly the forehead, preauricular area, and scalp, often in a superficial temporal artery distribution. Tumors have also been documented in the extremities (arm, triceps, hand, tibia, and foot) and less frequently in the trunk (rib, vertebra, axilla, neck, and clavicle). Lesion sites in soft tissue include the lacrimal gland [12], inner canthus [13], heart [14], eye [15], penis [16], scrotum [17], testis [18], colon [19], oral mucosa [20], arteries of the limbs [21], bone [4], lymph nodes [22], lung [23], tongue [24], breast [25], and spleen [26].

\section{Radiologic findings}

$\mathrm{X}$-ray imaging is generally ineffective for bone EH diagnosis because there are no distinguishing radiologic features. On conventional X-rays, the lesions are usually lucent with well-defined expansile margins [4]. They can also show a mixed lytic and sclerotic appearance with septations, partial cortical destruction, and thick periosteal reactive bone formation (Figure 6) [10]. 


\section{Cureus}

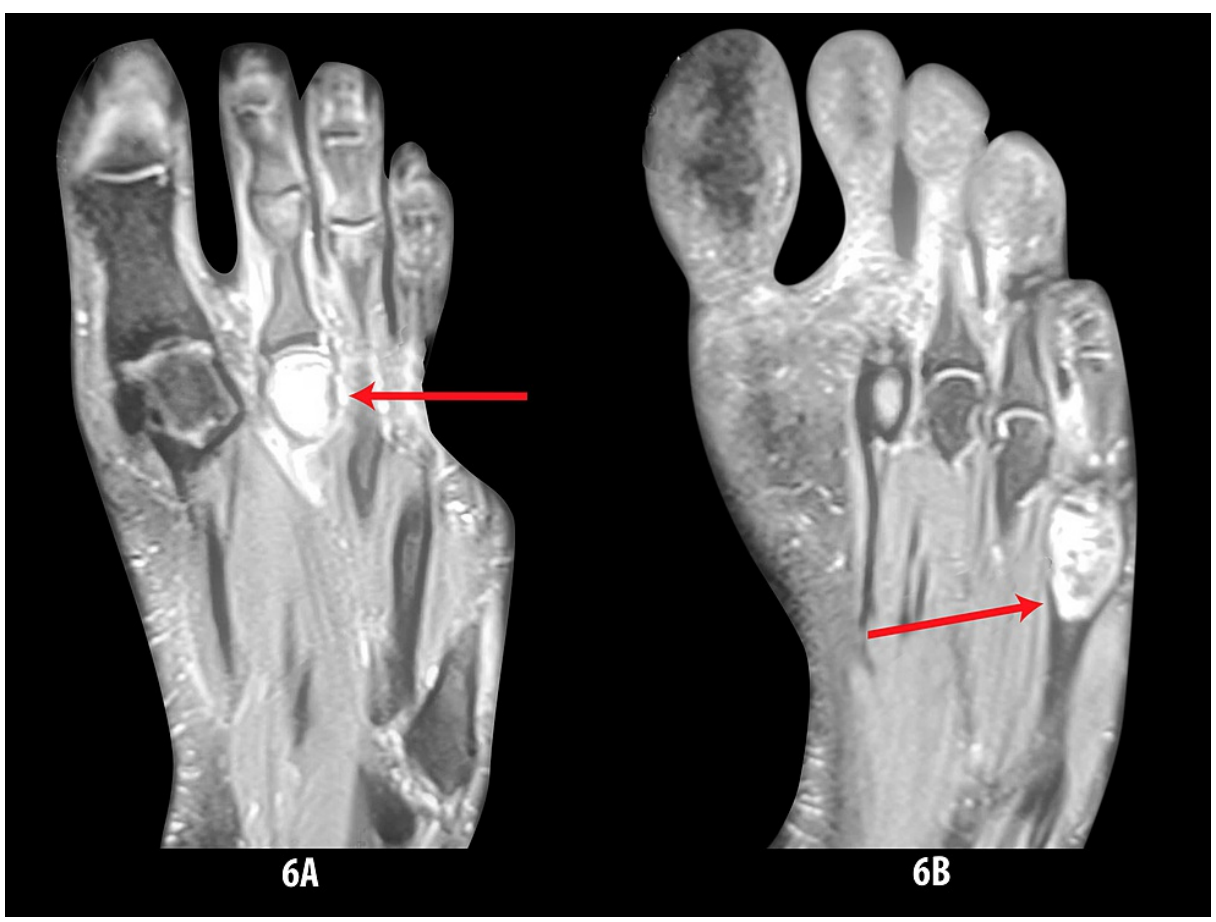

FIGURE 6: 6A and 6B: Radiology showing osteolytic and sclerosing lesions in metatarsal bone

However, differential diagnoses based on these plain radiographic features are non-specific and can include giant cell tumor, aneurysmal bone cyst, brown tumor, infectious spondylitis, and metastatic deposits. Similar to plain X-ray, computed tomography (CT) scans of bone EH show well-defined, septate, expansile, lytic lesions with cortical destruction and bony expansion. Bone EH is well-defined by MRI, being hypointense or isointense relative to muscle on T1-weighted images, and hyperintense on T2-weighted images. Lesions are markedly enhanced by gadolinium contrast, but even non-contrast MRI reveals welldefined lesions that are isointense or slightly hyperintense relative to skeletal muscle on T2-weighted images. There is variable surrounding marrow edema and enhancement. Cortical disruption with periosteal reaction can also be seen. Moreover, similar imaging manifestations, including multifocal presentation, aggressive radiologic appearance, and/or lymph node metastasis, may be present in both benign and malignant types; therefore, it should not be considered definitive for the differential diagnosis [2,10,27].

\section{Molecular events and pathogenesis}

The ALHE/EH etiology is currently unclear. Various hypotheses have been established, including a reactive process [27], a neoplastic process [28], and infectious mechanisms, including a possible association with human immunodeficiency virus (HIV) [29]; however, none are conclusive. EH may arise from an unusual reactive process following local trauma [27], infection [29], arteriovenous shunting [30], or hyperestrogenemia [31]. Further trauma by inciting cellular proliferation may “open the door" for a cytogenetic event [32], albeit one with limited biological (proliferative/growth) potential. Recent studies have demonstrated distinct molecular cytogenetic events contributing to tumorigenic pathways in $\mathrm{EH}$ and EHE. FOS gene fusion involvement could be a highly specific EH driving event because fusion events have been identified in one-third of cases across multiple anatomic locations (but with greater prevalence in intraosseous locations). Furthermore, ZFP36-FOSB fusion was identified in a subset of EH cases with atypical histological features by FOSB immunohistochemical expression [32]. Furthermore, distinctive WWTR1-CAMTA1 and YAP1-TFE3 gene fusions have been identified in EHE but not in other epithelioid vascular tumors [33,34]. These findings identify objective molecular tools for distinguishing EH from EHE, which is of paramount importance considering the greater aggression of the latter. However, a subset of cases of pseudomyogenic haemangioendothelioma harbors a $\mathrm{t}(7 ; 3)(\mathrm{q} 22 ; \mathrm{q} 13)$ translocation that also leads to the SERPINE1-FOSB gene fusion [35]. SERPINE1 encodes the plasminogen activator inhibitor-1, which is highly expressed in endothelial cells. FOSB fusions are also found in a subset of EH, and although they do not show significant morphologic overlap with $\mathrm{PMH}$, this lends credence to the idea that FOSB oncogenic activation is an important event in some benign and intermediate-grade vascular neoplasms.

\section{Cellular events and pathogenesis}

A cause-and-effect relationship has been suggested between trauma and reparative endothelial proliferation. Traumatic damage to vessel walls exposes endothelial cells to excessive arterial pressure and 
inflammation-associated cytokines, causing these cells to proliferate and acquire a round or oval epithelioid morphology with abundant eosinophilic cytoplasm [36]. The cells also develop cytoplasmic vacuoles representing the earliest stage of vessel lumen formation; their fusion results in vascular spaces with varying degrees of differentiation [4]. Proliferation and further differentiation of these cells result in vessel formation to constrain or divert the arterial pressure. These newly formed vessels show hob nailing of luminal cells. As lesions mature, they exhibit symmetric association with muscular arteries and increased peripheral maturation over time.

\section{Microscopic features}

Accurate assessment of lesional microscopic features and IHC expression profile is of paramount importance for the differential diagnosis of these epithelioid vascular neoplasms. The morphologic features of these tumors depend on the formation stage and soft tissue/bone location as well as on the presence and nature of vascular and inflammatory components. In all types, neoplastic cells are of endothelial immune phenotype. Typical variants are mature lesions with well-defined vasoformative tendency and vessel formation increasing from the center to the periphery [36]. At the center of the lesion, solid sheets of endothelial cells are observed (Figures 1-2), whereas the periphery may contain fully canalized vessels with a defined smooth muscle coat and epithelioid endothelial cell lining (Figures 3a, 3c). The epithelioid endothelial cells constituting the neoplasm are generally large and polyhedral, often contain abundant dense eosinophilic cytoplasm, and have a hobnail morphology in the lumen (resulting in a tombstone pattern, see Figures $3 b, 3 d$ ) [2]. In some tumors, however, the cytoplasm has a finer, feathery, or foamy vacuolated appearance, resembling that of histiocytic cells. Cytologic atypia is usually mild, but occasional cell foci with moderate nuclear pleomorphisms are observed, including multilobular nuclei or pseudonuclear inclusions. In addition to this general absence of cytologic atypia, these lesions show little mitotic activity or necrosis, with mitotic figures typically found at $<1 / 10 \mathrm{hpf}$ and always of normal structure [2,37]. Although most tumors are purely epithelioid, large spindling areas containing short fusiform or oval bland endothelial cells are also observed (Figures $2 a-2 c$ ) [2,38]. Hence, focal spindling and abundant hemorrhage are common in EH (Figures $2 b-2 c$ ) and thus cannot be used as exclusion criteria. The term "hemangioendothelioma, not otherwise specified" of the bone is a "catch-all" diagnosis and should be avoided where possible [2,38-39]. Other more infrequent findings include scattered intratumoral osteoclasttype giant cells and reactive bone formation that can compartmentalize the tumor into small nodules. In such cases, the tumor stroma comprises loose connective tissue and a prominent inflammatory infiltrate rich in eosinophils (Figure 4), lymphocytes, and plasma cells [40-44].

Subtle histomorphologic differences exist among EH of the skin, dermis, and bone, as summarized in Table 2. 


\section{Cureus}

\begin{tabular}{|c|c|c|c|}
\hline & EH of the skin and subcutaneous tissue & EH of soft tissue & EH of the bone \\
\hline $\begin{array}{l}\text { Neoplastic } \\
\text { potential of the } \\
\text { vascular } \\
\text { component }\end{array}$ & $\begin{array}{l}\text { Reactive lesion to trauma. Angiocentric distribution } \\
\text { around a larger vessel with evidence of mural } \\
\text { damage often associated with trauma. }\end{array}$ & $\begin{array}{l}\text { Reactive lesion to trauma. } \\
\text { However, a case of dermal } \\
\text { EH was found to harbor a } \\
\text { TEK gene mutation, which } \\
\text { encodes the endothelial } \\
\text { cell tyrosine kinase } \\
\text { receptor Tie-2, indicating } \\
\text { that certain molecular } \\
\text { abnormalities may also } \\
\text { contribute to pathogenesis } \\
\text { [41]. }\end{array}$ & $\begin{array}{l}\text { Distinct cytogenetic events } \\
\text { and lack of an eosinophilic } \\
\text { response in some tumors } \\
\text { suggest distinct } \\
\text { pathogenesis compared with } \\
\text { that in skin EH. FOS gene } \\
\text { rearrangement and recurrent } \\
\text { ZFP36-FOSB fusion are } \\
\text { present in nearly one-third of } \\
\text { bone EH cases in varied } \\
\text { locations [32]. }\end{array}$ \\
\hline $\begin{array}{l}\text { Neoplastic } \\
\text { potential of the } \\
\text { inflammatory cell } \\
\text { component }\end{array}$ & \multicolumn{2}{|c|}{$\begin{array}{l}\text { These lesions are associated with various lymphoproliferative conditions, } \\
\text { supporting the contention that some EH cases arise from a monoclonal T-cell } \\
\text { process [42]. Peripheral T-cell lymphoma was reported in a patient with ALHE/EH. } \\
\text { Some cases of ALHE/EH have also been reported with T-cell receptor gene } \\
\text { rearrangement and monoclonality [42]. }\end{array}$} & $\begin{array}{l}\text { Mostly polyclonal and } \\
\text { reactive. No } \\
\text { lymphoproliferative } \\
\text { conditions documented to } \\
\text { date. }\end{array}$ \\
\hline Margins & Well-marginated lesions. & $\begin{array}{l}\text { Less-marginated lesions } \\
\text { [33]. }\end{array}$ & Less-marginated lesions. \\
\hline $\begin{array}{l}\text { Association with } \\
\text { an artery }\end{array}$ & $\begin{array}{l}\text { Demonstrable angiocentric distribution and } \\
\text { symmetric association with an artery. The artery can } \\
\text { show evidence of damage (e.g., thrombosis, } \\
\text { fibrointimal proliferation, duplication of the internal } \\
\text { elastic lamina, or mural disruption) [43]. }\end{array}$ & $\begin{array}{l}\text { Rarely associated with a } \\
\text { muscular artery [33]. }\end{array}$ & $\begin{array}{l}\text { Symmetrical association with } \\
\text { an artery is not usually } \\
\text { demonstrable in bone lesions } \\
\text { because the site of origin } \\
\text { may be obliterated by the } \\
\text { expanding tumor [2]. }\end{array}$ \\
\hline $\begin{array}{l}\text { Vasoformative } \\
\text { tendency }\end{array}$ & $\begin{array}{l}\text { Vasoformative tendency and vessel maturation } \\
\text { increase from the center to the periphery, resulting in } \\
\text { central ill-defined poorly formed vessels (Fig 2) and } \\
\text { peripheral well-formed vessels (Fig 3). The } \\
\text { subcutaneous form has a tendency for the florid } \\
\text { proliferation of large epithelioid endothelial cells that } \\
\text { may become so exuberant as to form solid } \\
\text { intraluminal nodules or clusters. These masses can } \\
\text { obscure the vascular nature of the lesion and thus } \\
\text { increase the diagnostic complexity [44-45]. }\end{array}$ & $\begin{array}{l}\text { Similar vasoformative } \\
\text { tendency to EH of the skin } \\
\text { but lesions contain more } \\
\text { fully developed vessels, } \\
\text { typically with patent } \\
\text { lumina. [33]. }\end{array}$ & $\begin{array}{l}\text { Vasoformativetendency but } \\
\text { often greater histological } \\
\text { variability within lesions. }\end{array}$ \\
\hline Histomorphology & $\begin{array}{l}\text { Well-defined epithelioid endothelial morphology } \\
\text { (Figure 3). }\end{array}$ & $\begin{array}{l}\text { Less pronounced } \\
\text { epithelioid endothelial } \\
\text { morphology (often more } \\
\text { cobblestone-like) [36]. }\end{array}$ & $\begin{array}{l}\text { Recognizable epithelioid } \\
\text { endothelial morphology. } \\
\text { Spindling and fasciculation } \\
\text { may be observed within the } \\
\text { lesion [37]. }\end{array}$ \\
\hline
\end{tabular}

\section{TABLE 2: Histological features of epithelioid hemangioma (EH) in different tissues}

Further, bone EH shows a greater degree of histologic variability than skin and soft-tissue EH [2]. Depending on the EH developmental stage, vascular or inflammatory components may predominate. In early or actively growing EHs, the vascular component predominates, whereas, in late stages, lymphocytes become more prominent. The vessels in early ALHE/EH are immature with prominent epithelioid endothelial cells; however, when the lymphoid infiltrate predominates in the later stage, endothelial cells lining the maturing vessels become smaller and less epithelioid. Confounding histomorphologic features of vascular and inflammatory components.

\section{When the Vascular Component Predominates}

The vasoformative tendency of the vascular component generally decreases from lesion center to periphery. The central indeterminate solid component can predominate in exuberant or atypical variants. The differential diagnoses in such cases are EHE [9], EAS [41], and very rarely, Kaposi sarcoma. Detailed histological evaluation is critical in such equivocal cases to prevent overly aggressive intervention. A number of histological parameters must be assessed (Table 3), and if the sample size is too small to establish 


\section{Cureus}

a diagnosis with confidence, additional sampling should be requested.

\begin{tabular}{|c|c|c|c|c|}
\hline $\begin{array}{l}\text { Histomorphological } \\
\text { features }\end{array}$ & EH & EHE & $\begin{array}{l}\text { Pseudomyogenic } \\
\text { hemangioendothelioma }\end{array}$ & EAS \\
\hline Neoplastic nature & $\begin{array}{l}\text { Benign with metastasizing potential } \\
\text { [46]. }\end{array}$ & Intermediate [46]. & Intermediate [47]. & High-grade [4]. \\
\hline \multirow[t]{2}{*}{$\begin{array}{l}\text { Association with } \\
\text { artery }\end{array}$} & $\begin{array}{l}\text { Intimately associated with and } \\
\text { symmetrically distributed with a small } \\
\text { muscular artery. }\end{array}$ & $\begin{array}{l}\text { Lacks intimate association } \\
\text { with a muscular artery } \\
\text { [4]. Typically affects the } \\
\text { veins rather than arteries } \\
\text { [4]. }\end{array}$ & $\begin{array}{l}\text { Lacks intimate association } \\
\text { with a muscular artery [4]. }\end{array}$ & $\begin{array}{l}\text { Lacks intimate } \\
\text { association with a } \\
\text { muscular artery [4]. }\end{array}$ \\
\hline & $\begin{array}{l}\text { Presence of mature vessel foci with } \\
\text { open lumen formation [25]. }\end{array}$ & Mature vessels absent [4]. & Mature vessels absent [4]. & $\begin{array}{l}\text { Mature vessels } \\
\text { absent [4]. }\end{array}$ \\
\hline $\begin{array}{l}\text { Molecular } \\
\text { pathology }\end{array}$ & $\begin{array}{l}\text { FOS gene rearrangement in nearly } 1 / 3 \\
\text { of EH cases in various locations } \\
\text { [32]. Recurrent ZFP36-FOSB fusion in a } \\
\text { subset of EH cases with atypical } \\
\text { morphological features that do not } \\
\text { suggest FOS gene rearrangement } \\
\text { [48]. Recurrent ZFP36-FOSB fusion in a } \\
\text { subset of EH cases with atypical } \\
\text { histological features. Confirmed FOSB- } \\
\text { positive by immunohistochemistry [48]. } \\
\text { Negative for WWTR1-CAMTA1 fusion } \\
\text { [48]. }\end{array}$ & $\begin{array}{l}\text { Recurrent } \mathrm{t}(1 ; 3)(\mathrm{p} 36 ; \mathrm{q} 25) \\
\text { chromosomal } \\
\text { translocation, resulting in } \\
\text { WWTR1-CAMTA1 fusion } \\
\text { [37]. }\end{array}$ & $\begin{array}{l}\text { SERPINE1-FOSB fusion } \\
\text { [47]. }\end{array}$ & $\begin{array}{l}\text { Complex } \\
\text { cytogenetic } \\
\text { aberrations. No } \\
\text { WWTR1-CAMTA1 } \\
\text { fusion or FOS gene } \\
\text { rearrangement [37]. }\end{array}$ \\
\hline Sites & $\begin{array}{l}\text { Femur, phalanges, tibia, fibula, } \\
\text { metatarsals, scapula, humerus, ilium, } \\
\text { vertebrae, sacrum, ribs, and sternum } \\
\text { [5]. }\end{array}$ & $\begin{array}{l}\text { May involve any bone and } \\
\text { has been detected in the } \\
\text { femur, tibia, fibula, } \\
\text { humerus, radius, ulna, ribs, } \\
\text { vertebral bodies, pelvis, } \\
\text { scapula, and small bones } \\
\text { of the hands and feet [49]. }\end{array}$ & $\begin{array}{l}\text { Superficial or deep soft } \\
\text { tissue of extremities [47]. }\end{array}$ & $\begin{array}{l}\text { Predilection for the } \\
\text { femur. Other } \\
\text { affected bones } \\
\text { include the tibia, } \\
\text { calcaneus, } \\
\text { humerus, radius, } \\
\text { and small bones of } \\
\text { the hand, rib, and } \\
\text { pelvis [50] }\end{array}$ \\
\hline Multifocality & Unicentric to multicentric [4]. & $\begin{array}{l}\text { Unicentric to multicentric } \\
\text { [49]. }\end{array}$ & Multicentric [47]. & $\begin{array}{l}\text { Unicentric to } \\
\text { multicentric [50]. }\end{array}$ \\
\hline Age & $\begin{array}{l}\text { Second to eighth decades of life (mean } \\
\text { age of } 34 \text { years) [20]. }\end{array}$ & $\begin{array}{l}\text { Slight male predominance } \\
\text { and a wide age distribution } \\
\text { extending from the second } \\
\text { to eighth decades of life } \\
\text { [49]. }\end{array}$ & Males. Young adults. [47] & $\begin{array}{l}\text { Striking male } \\
\text { predominance with } \\
\text { a mean age of } 57 \\
\text { years [50]. }\end{array}$ \\
\hline Gross & $\begin{array}{l}\text { Ranges from } 2 \text { to } 15 \mathrm{~cm} \text { in the biggest } \\
\text { dimension, well-circumscribed, and } \\
\text { dark red in color. Mostly confined to the } \\
\text { affected bone where they infiltrate the } \\
\text { marrow space, surround the bony } \\
\text { trabeculae, and abut or erode the } \\
\text { cortex. Occasionally, large tumors } \\
\text { transgress the cortex and form soft- } \\
\text { tissue masses [51]. }\end{array}$ & $\begin{array}{l}\text { Ranges from } 2 \mathrm{~cm} \text { to }>10 \\
\mathrm{~cm} \text {. Frequently tan in color } \\
\text { and solid in structure. } \\
\text { Usually centered in the } \\
\text { medullary cavity and grow } \\
\text { in an infiltrative and } \\
\text { destructive fashion [49]. }\end{array}$ & $\begin{array}{l}\text { Ranges from } 1 \text { to } 2.5 \mathrm{~cm} \\
\text { only with approximately } \\
10 \% \text { of tumors being }>3 \mathrm{~cm} \\
\text { [47]. Grossly, the tumor is } \\
\text { ill-defined, usually } \\
\text { multifocal, with a white-to- } \\
\text { brown cut surface [47]. }\end{array}$ & $\begin{array}{l}\text { Usually }>5 \mathrm{~cm} \text { and } \\
\text { soft, red, and } \\
\text { hemorrhagic. } \\
\text { Usually originates } \\
\text { in the medullary } \\
\text { cavity and invades } \\
\text { the cortex and } \\
\text { neighboring soft } \\
\text { tissues [50]. }\end{array}$ \\
\hline Radiology & $\begin{array}{l}\text { Usually lucent with well-defined } \\
\text { expansile margins [20]. In some cases, } \\
\text { they show a mixed lytic and sclerotic } \\
\text { appearance with septations, partial } \\
\text { cortical destruction, and thick } \\
\text { periosteal reactive bone formation [6]. }\end{array}$ & $\begin{array}{l}\text { Usually lytic or mixed lytic } \\
\text { and blastic with well- or } \\
\text { poorly defined margins. } \\
\text { Can expand the bone } \\
\text { contour and elicit a } \\
\text { periosteal reaction, } \\
\text { especially if a soft-tissue } \\
\text { component is present [49]. }\end{array}$ & $\begin{array}{l}\text { Usually lytic, lobulated, and } \\
\text { well-circumscribed on CT } \\
\text { and radiography. On MRI, } \\
\text { the lesions are hypointense } \\
\text { on T1-weighted images and } \\
\text { hyperintense on T2- } \\
\text { weighted and stir-weighted } \\
\text { images [47]. }\end{array}$ & $\begin{array}{l}\text { Predominantly } \\
\text { destructive or } \\
\text { exclusively lytic, } \\
\text { frequently } \\
\text { extending into soft } \\
\text { tissues. }\end{array}$ \\
\hline
\end{tabular}




\section{Cureus}

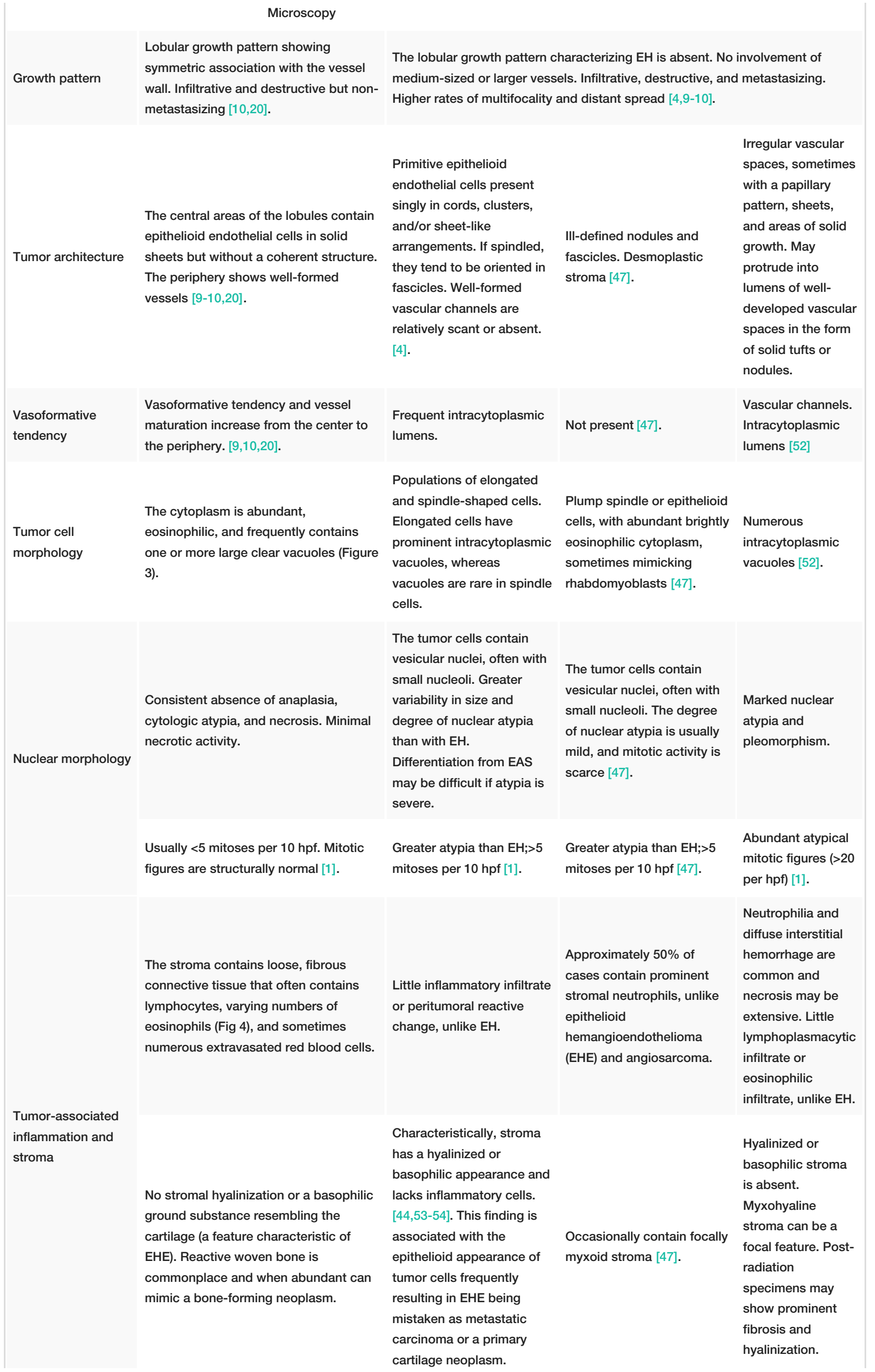




\section{Cureus}

\begin{tabular}{|c|c|c|c|c|}
\hline $\begin{array}{l}\text { IHC for muscle- } \\
\text { specific actin }\end{array}$ & Zonation pattern [33]. & No zonation pattern. & No zonation pattern. & $\begin{array}{l}\text { No zonation } \\
\text { pattern. }\end{array}$ \\
\hline $\begin{array}{l}\text { Other IHC markers } \\
\text { and their predictive } \\
\text { values. }\end{array}$ & 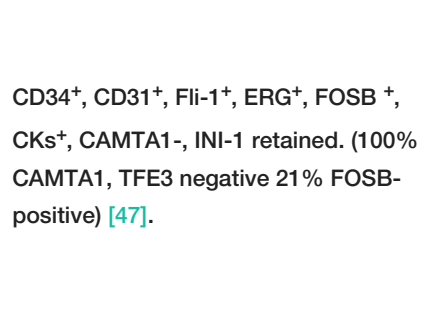 & $\begin{array}{l}{\text { CD } 34^{+}, \text {CD } 31^{+}, \text {Fli-1 }}^{+} \text {, } \\
\text { ERG }{ }^{+} \text {FOSB -, } \text { CKs }^{+}, \\
\text {CAMTA1 } 1^{+} \text {INI-1 retained. } \\
\text { (100\% FOSB-negative, } \\
62 \% \text { CAMTA1-positive- } \\
\text { TFE3 negative, 38\% } \\
\text { CAMTA1-negative, TFE3- } \\
\text { positive) [47]. }\end{array}$ & $\begin{array}{l}\text { CD34-, CD31+, Fli-1+, ERG }{ }^{+} \text {, } \\
\text { FOSB }{ }^{+}, \mathrm{CKs}^{+}, \text {CAMTA1 -, } \\
\text { INI-1 retained. (100\% } \\
\text { CAMTA1, TFE3 negative, } \\
\text { 100\% FOSB-positive) [47]. }\end{array}$ & $\begin{array}{l}\mathrm{CD}^{+} 4^{+}(50 \%), \\
\mathrm{CD}^{+} 1^{+}, \mathrm{Fli1}^{+}, \mathrm{ERG}^{+} \text {, } \\
\text { FOSB -, } \mathrm{CKs}^{+}, \\
\text {CAMTA1 -, INI-1 } \\
\text { retained. (100\% - } \\
\text { CAMTA1,TFE3- } \\
\text { negative, FOSB- } \\
\text { negative) [47]. }\end{array}$ \\
\hline Treatment & $\begin{array}{l}\text { Depending on the size and location of } \\
\text { the lesion(s), curettage, conservative en } \\
\text { block excision, or wide resection is } \\
\text { recommended. }\end{array}$ & $\begin{array}{l}\text { The number, size, location, } \\
\text { and stage of the tumor } \\
\text { determine the treatment } \\
\text { type. Wide resection is } \\
\text { recommended when } \\
\text { feasible. Chemotherapy } \\
\text { has been suggested for } \\
\text { widespread multisystemic } \\
\text { involvement. }\end{array}$ & $\begin{array}{l}\text { The treatment of choice has } \\
\text { been surgery (wide } \\
\text { resection), with certain } \\
\text { cases receiving } \\
\text { radiotherapy or } \\
\text { chemotherapy. Recently, } \\
\text { high expression of mTOR } \\
\text { has been demonstrated by } \\
\text { immunohistochemistry, and } \\
\text { two cases treated with } \\
\text { mTOR inhibitors showed } \\
\text { clinical improvement }[7,36] \text {. }\end{array}$ & $\begin{array}{l}\text { Wide surgical } \\
\text { resection with or } \\
\text { without adjuvant } \\
\text { radiation and } \\
\text { chemotherapy. } \\
\text { These tumors have } \\
\text { an extremely high } \\
\text { rate of metastasis } \\
\text { and virtually all } \\
\text { patients die within } \\
1-2 \text { years of } \\
\text { diagnosis. }\end{array}$ \\
\hline
\end{tabular}

\section{TABLE 3: Clinical and histological features distinguishing EH, EHE, and EAS}

EH: epithelioid hemangioma; EHE: epithelioid hemangioendothelioma; EAS: epithelioid angiosarcoma

As one factor for distinguishing possible EH, both EHE and EAS less frequently involve the bone [2]. Although once described as distinct entities, hemorrhagic epithelioid and spindle cell hemangioma are now considered EH variants [37]. The typical nodular EH variants can resemble pyogenic granuloma, which comprises tight aggregates of capillary-sized vessels growing in a lobular fashion within a fibromyxoid (granulation tissue-like) stroma [45,55]. EH can also exhibit intravascular papillary endothelial cell proliferation; this feature can confound the differential diagnosis from intravascular papillary endothelial hyperplasia (Masson's tumor) [21]. However, vessels with an irregular lumen and plump epithelioid cells are typically absent in the latter [21]. The differential diagnoses for other cutaneous lesions mainly comprising epithelioid cells include poorly differentiated squamous cell carcinoma, melanoma, epithelioid vascular tumor, atypical fibroxanthoma, cutaneous leiomyosarcoma, epithelioid fibrous histiocytoma, and epithelioid sarcoma [56]. The IHC staining profile should be considered for classifying tumor lineage in such cases.

When the Inflammatory Component Predominates

The predominance of inflammatory components has greater diagnostic implications for soft-tissue lesions. The mixed inflammatory infiltrate is nodular and presents a perivascular and periadnexal distribution. Lymphocytes, histiocytes, eosinophils, mast cells, and plasma cells are scattered [57]. When the mixed inflammatory infiltrate predominates or obscures the vascular component, EH can be misdiagnosed as Kimura's disease, response to an arthropod bite, or cutaneous lymphoproliferative disorders, among others (Tables 4-6) [57-63]. The key to EH diagnosis in such cases is recognizing the vascular component of the lesion [57]. 


\section{Cureus}

\begin{tabular}{|l|l|l|}
\hline & Epithelioid haemangioma & Kimura's disease \\
\hline Ethnicity & Occurs in all ethnicities [57]. & Predominantly affects Asian males [57]. \\
\hline Location & Superficial and smaller lesions [57]. & $\begin{array}{l}\text { Subcutaneous involvement with extension to lymph nodes, } \\
\text { underlying soft tissue, and salivary glands [5]]. }\end{array}$ \\
$\begin{array}{l}\text { Complete blood } \\
\text { counts and serology }\end{array}$ & $\begin{array}{l}\text { Lacks high IgE and eosinophils in peripheral } \\
\text { blood [57]. }\end{array}$ & $\begin{array}{l}\text { High IgE, eosinophils in peripheral blood, and eosinophilia. } \\
\text { Could be misdiagnosed as nephrotic syndrome, asthma, } \\
\text { tuberculosis, or Loeffler syndrome [57]. }\end{array}$ \\
$\begin{array}{l}\text { Epithelioid } \\
\text { morphology }\end{array}$ & $\begin{array}{l}\text { Epithelioid endothelial cells line all blood } \\
\text { vessels [57]. }\end{array}$ & $\begin{array}{l}\text { Proliferation of post-capillary venules lined by plump } \\
\text { endothelial cells [57]. }\end{array}$ \\
$\begin{array}{l}\text { Overlapping } \\
\text { morphologic features }\end{array}$ & $\begin{array}{l}\text { Lymph follicles with germinal center } \\
\text { formation and abundant eosinophils (less } \\
\text { intense than in Kimura's disease) [57]. }\end{array}$ & $\begin{array}{l}\text { Lymph follicles with germinal center formation and abundant } \\
\text { eosinophils (more intense than in EH) [57]. }\end{array}$ \\
$\begin{array}{l}\text { Eosinophilic } \\
\text { microabscesses and } \\
\text { Charcot-Leyden } \\
\text { crystals }\end{array}$ & Negative [57]. & Present [57]. \\
\hline
\end{tabular}

\section{TABLE 4: Distinguishing EH from Kimura's disease}

EH: epithelioid hemangioma

\begin{tabular}{|l|l|l|}
\hline \hline & Epithelioid hemangioma & Cutaneous marginal zone lymphoma \\
\hline $\begin{array}{l}\text { Pattern of } \\
\text { inflammation }\end{array}$ & Nodular polyclonal perivascular or periappendigeal lymphocytic infiltrate with CD30 \\
\hline $\begin{array}{l}\text { Added features } \\
\text { Epithelioid } \\
\text { vascular } \\
\text { component }\end{array}$ & $\begin{array}{l}\text { Absence of factors listed } \\
\text { (right panel) [58]. }\end{array}$ & $\begin{array}{l}\text { Dutcher bodies, lymphoplasmacytoid cells, folliculotropism and syringotropism, } \\
\text { monoclonality, and aberrant BCL2 expression [58]. }\end{array}$ \\
\hline & $\begin{array}{l}\text { Prominent epithelioid } \\
\text { vascular component [58]. }\end{array}$ & No epithelioid vascular component [58]. \\
\hline
\end{tabular}

TABLE 5: Distinguishing EH from cutaneous marginal zone lymphoma

EH: epithelioid hemangioma

Epithelioid hemangioma

Extent of

capillary

proliferation

Growth pattern
Marked capillary proliferation [59-63].

Lobular growth pattern with numerous epithelioid endothelial cells [59-63].

\section{Arthropod bite}

Subtle capillary proliferation [59-63].

No lobular orientation and relatively

few endothelial cells [59-63].
Cutaneous epithelioid angiomatous nodules

Sheet-like proliferation of endothelial cells in skin [63].

No multilobular growth pattern as seen in $\mathrm{EH}$ [63].

\section{TABLE 6: Distinguishing EH from an arthropod bite response and cutaneous epithelioid} angiomatous nodules

EH: epithelioid hemangioma 


\section{Metastasis versus multi-centricity of EH}

Based on recent findings, EH is now considered a benign vascular tumor with a metastatic potential of monoclonal origin (18\%-25\% of tumors) [37,64-65]. Van Ijzendoorn et al. provided evidence that multifocal EH results from metastasis of the same neoplastic clone rather than the simultaneous neoplastic formation of multiple EH cell clones [46,54]. Similarly, a case with multifocal EHE of the liver also demonstrated monoclonality [46]. Therefore, multifocal vascular tumors of this type are more likely to be metastatic than multicentric. To date, there have been no reports of fatal $\mathrm{EH}$ metastasis, consistent with the current classification [35].

\section{Role of IHC in the differential diagnosis}

HHF-35 immunohistochemistry is considered the best available marker (far superior to smooth muscle actin) for confirming the presence of an intact myopericytic layer around immature vessels. The presence of this layer, particularly when its distribution increases from the central to peripheral zones (zonation), is a good indication of lesional maturation. Although this zonation pattern is clearly present in EHE and EAS, it is typically nowhere near as distinct or prevalent as in $\mathrm{EH}$ [33]. A small fraction of lesional epithelioid endothelial cells express keratins [38]. This expression can hinder diagnosis because it is a common sign of epithelial neoplasms. However, if attention is paid to the limited extent of the reaction and CD31 and factor VIIIrAg levels are also examined, an incorrect diagnosis of "epithelial neoplasm" can be prevented. Preliminary observations suggest that keratin expression is more frequent in malignant epithelioid vascular tumors than in EH (Figure 5). The other IHC markers that can be used include FLI-1, ERG, FOSB, CAMTA1, TFE-3, and INI-1 [47]. The varying pattern of expression of the above markers among the epithelioid vascular neoplasms helps in the proper subcategorization of the neoplasms, as depicted in Table 3 [47].

\section{Next-generation sequencing and the role of reverse transcription- polymerase chain reaction (RT-PCR) in the classification of epithelioid vascular neoplasms}

Immunophenotypic and molecular characterization of these tumors has developed significantly over the last 10 years, as demonstrated in the WHO categorization. A genetic signature of epithelioid hemangioma has been recognized as chromosomal translocation including the FOS gene [32] while rearrangements involving FOSB [47] have been observed in pseudomyogenic hemangioendothelioma and a subset of epithelioid hemangiomas. Such molecular modifications are important diagnostic indicators that can help separate these two tumors from several other vascular tumors. In addition, two novel recurring gene combinations (WWTR1-CAMTA1 and YAP1-TFE3 gene fusions) have been reported for epithelioid hemangioendothelioma [37]. Until now, in all the morphologic mimics of epithelioid hemangioendothelioma, these genetic variations haven't been identified, thereby representing an additional diagnostic instrument. Intriguingly, these mergers contributed to the mutually unique nuclear aggregation of CAMTA1 or TFE3, allowing IHC to be a reliable solution for all variants of epithelioid hemangioendothelioma (Table 3) [47].

\section{Treatment modalities and clinical behavior of EH}

Previously, most EHs were conservatively treated, as they were not aggressive [2,66-68]. Indeed, many EH case reports encompass several origin sites and distributions, indicating that this disease does not show disseminated growth that can be construed as aggressively destructive or life-threatening; this supports the concept that bone EH is benign similar to its cutaneous counterpart. The benign nature of this tumor is further supported by reports of spontaneous regression [68]. The simultaneous involvement of multiple organ systems is likely a manifestation of monoclonality with metastatic behavior. Nonetheless, there are no recorded fatalities from metastasis. Although epithelioid bone vascular tumors share only some overlapping morphological and clinical features, they markedly differ in prognosis and recommended management. Based on our experience, we believe that bone EH should be treated with curettage or marginal en bloc excision when appropriate and that this treatment will result in an excellent prognosis $[2,4]$. However, EHE and EAS should be widely excised and systemic therapy should be considered because these tumors, particularly EAS, can be fatal $[2,4]$. Thus, it is critical to distinguish EHE and EAS from EH based on morphologic criteria. Moreover, in current advanced molecular diagnostics, one cannot overemphasize the importance of detecting FOS gene rearrangements and recurrent ZFP36-FOSB in the subsets of cases of EH [32]. Recurrent $\mathrm{t}(1 ; 3)(\mathrm{p} 36 ; \mathrm{q} 25)$ chromosomal translocation, resulting in WWTR1CAMTA1 fusion, are seen in a subset of cases of EHE [37]. Judicious usage of these molecular fusion markers can be of immense help in differentiating morphologically close, overlapping cases of EH and EHE. Osseous epithelioid endothelial tumors should be classified into three tiers, analogous to their soft-tissue counterparts, and this approach might help clarify the historic confusion surrounding these entities $[2,10,66,69]$.

\section{Conclusions}

In summary, three cases of bone $\mathrm{EH}$ are reported, and the relevant literature describing the classic features distinguishing this disease from other bone epithelioid vascular tumors is summarized in this case series. However, there is no individual early clinical, radiological, or immunohistochemical marker for distinguishing this benign form from other, more aggressive bone vascular tumors. Rather, multiple 
histologic and IHC parameters must be assessed, and if the sample size is too small to establish a diagnosis with confidence, additional sampling should be requested. It is mandatory to judiciously use ancillary molecular diagnostic techniques for the screening of FOS gene rearrangements and WWTR1-CAMTA1 and YAP1-TFE3 gene fusions for the subtle morphologic differentiation of EH and EHE when necessary.

\section{Additional Information \\ Disclosures}

Human subjects: Consent was obtained or waived by all participants in this study. Conflicts of interest: In compliance with the ICMJE uniform disclosure form, all authors declare the following: Payment/services info: All authors have declared that no financial support was received from any organization for the submitted work. Financial relationships: All authors have declared that they have no financial relationships at present or within the previous three years with any organizations that might have an interest in the submitted work. Other relationships: All authors have declared that there are no other relationships or activities that could appear to have influenced the submitted work.

\section{References}

1. Fletcher CDM, Unni KK, Mertens F: World Health Organization Classification of Tumours. Pathology and Genetics of Tumours of Soft Tissue and Bone. IARC Press, Lyon; 2002.

2. Nielsen GP, Srivastava A, Kattapuram S, Deshpande V, O'Connell JX, Mangham CD, Rosenberg AE: Epithelioid hemangioma of bone revisited: a study of 50 cases . Am J Surg Pathol. 2009, 33:270-7. 10.1097/PAS.0b013e31817f6d51

3. Evans HL, Raymond AK, Ayala AG: Vascular tumors of bone: a study of 17 cases other than ordinary hemangioma, with an evaluation of the relationship of hemangioendothelioma of bone to epithelioid hemangioma, epithelioid hemangioendothelioma, and high-grade angiosarcoma. Hum Pathol. 2003, 34:68089. 10.1016/s0046-8177(03)00249-1

4. O'Connell JX, Nielsen GP, Rosenberg AE: Epithelioid vascular tumors of bone: a review and proposal of a classification scheme. Adv Anat Pathol. 2001, 8:74-82. 10.1097/00125480-200103000-00003

5. Hartmann WH, Stewart FW: Hemangioendothelioma of bone. Unusual tumor characterized by indolent course. Cancer. 1962, 15:846-54. 10.1002/1097-0142(196207/08)15:4<846::aid-cncr2820150421>3.0.co;2-9

6. Rosai J, Gold J, Landy R: The histiocytoid hemangiomas: a unifying concept embracing several previously described entities of skin, soft tissue, large vessels, bone, and heart. Hum Pathol. 1979, 10:707-30. 10.1016/s0046-8177(79)80114-8

7. Weiss SW, Enzinger FM: Epithelioid hemangioendothelioma: a vascular tumor often mistaken for a carcinoma. Cancer. 1982, 50:970-81. 10.1002/1097-0142(19820901)50:5<970::aid-cncr2820500527>3.0.c0;2Z

8. Sardaro A, Bardoscia L, Petruzzelli MF, Portaluri M: Epithelioid hemangioendothelioma: an overview and update on a rare vascular tumor. Oncol Rev. 2014, 8:259. 10.4081/oncol.2014.259

9. O'Connell JX, Kattapuram SV, Mankin HJ, Bhan AK, Rosenberg AE: Epithelioid hemangioma of bone. A tumor often mistaken for low-grade angiosarcoma or malignant hemangioendothelioma. Am J Surg Pathol. 1993, 17:610-7.

10. Wenger DE, Wold LE: Benign vascular lesions of bone: radiologic and pathologic features . Skeletal Radiol. 2000, 29:63-74. 10.1007/s002560050012

11. Floris G, Deraedt K, Samson I, Brys P, Sciot R: Epithelioid hemangioma of bone: a potentially metastasizing tumor?. Int J Surg Pathol. 2006, 14:9-15; discussion 16-20. 10.1177/106689690601400102

12. Coombes AG, Manners RM, Ellison DW, Evans BT: Lacrimal gland epithelioid haemangioma. Br J Ophthalmol. 1997, 81:1020. 10.1136/bjo.81.11.e1016

13. Mariatos G, Gorgoulis VG, Laskaris G, Kittas C: Epithelioid haemangioma (angiolymphoid hyperplasia with eosinophilia) in the inner canthus. J Eur Acad Dermatol Venereol. 2001, 15:90-1. 10.1046/j.14683083.2001.00202-12.x

14. de Nictolis M, Brancorsini D, Goteri G, Prat J: Epithelioid haemangioma of the heart. Virchows Arch. 1996, 428:119-23. 10.1007/BF00193940

15. Miličić B, Velnar T, Pregelj R, Limbaeck-Stokin C: Multiple epithelioid hemangiomas with orbital involvement. Case Rep Pathol. 2015, 2015:629805. 10.1155/2015/629805

16. Ismail M, Damato S, Freeman A, Nigam R: Epithelioid hemangioma of the penis: case report and review of literature. J Med Case Rep. 2011, 5:260. 10.1186/1752-1947-5-260

17. Avallone AN, Avallone MA, Share S, Rubin BP: Epithelioid hemangioma-a rare scrotal tumor of childhood . Urology. 2012, 80:707-9. 10.1016/j.urology.2012.04.042

18. Liu X, Wang R, Guan W, Wang L: Epithelioid hemangioma of the testis. Indian J Pathol Microbiol. 2013, 56:422-4. 10.4103/0377-4929.125359

19. Nonose R, Priolli DG, Cardinalli IA, Máximo FR, Galvão PS, Martinez CA: Epithelioid hemangioma of the colon: a case report [Article in Portuguese]. Sao Paulo Med J. 2008, 126:294-6. 10.1590/s151631802008000500011

20. Sung MS, Kim YS, Resnick D: Epithelioid hemangioma of bone. Skeletal Radiol. 2000, 29:530-4. $10.1007 /$ s002560000254

21. Moira R, Giuseppe F, Riccardo V, et al.: Epithelioid hemangioma of brachial artery: report of a case and review of the literature. Open Med (Wars). 2015, 10:502-7. 10.1515/med-2015-0085

22. Elgoweini M, Chetty R: Primary nodal hemangioma. Arch Pathol Lab Med. 2012, 136:110-2. 10.5858/arpa.2010-0687-RS

23. Mesquita RD, Sousa M, Trinidad C, Pinto E, Badiola IA: New insights about pulmonary epithelioid hemangioendothelioma: review of the literature and two case reports. Case Rep Radiol. 2017, 2017:5972940. 
$10.1155 / 2017 / 5972940$

24. Shimoyama T, Horie N, Ide F: Epithelioid hemangioma of the tongue mimicking a malignancy . J Oral Maxillofac Surg. 2000, 58:1317-9. 10.1053/joms.2000.16640

25. Brodie C, Provenzano E: Vascular proliferations of the breast. Histopathology. 2008, 52:30-44. 10.1111/j.1365-2559.2007.02892.x

26. Wang Z, Zhang L, Zhang B, Mu D, Cui K, Li S: Hemangioendothelioma arising from the spleen: a case report and literature review. Oncol Lett. 2015, 9:209-12. 10.3892/ol.2014.2693

27. Stewart N, Zagarella S, Mann S: Angiolyphoid hyperplasia with eosinophilia occurring after venipuncture trauma. J Dermatol. 2013, 40:393-5. 10.1111/1346-8138.12106

28. Kempf W, Haeffner AC, Zepter K, et al.: Angiolymphoid hyperplasia with eosinophilia: evidence for a T-cell lymphoproliferative origin. Hum Pathol. 2002, 33:1023-9. 10.1053/hupa.2002.128247

29. D'Offizi G, Ferrara R, Donati P, Bellomo P, Paganelli R: Angiolymphoid hyperplasia with eosinophils in HIV infection. AIDS. 1995, 9:813-4. 10.1097/00002030-199507000-00023

30. Moesner J, Pallesen R, Sørensen B: Angiolymphoid hyperplasia with eosinophilia (Kimura’s disease). A case with dermal lesions in the knee region and a popliteal arteriovenous fistula. Arch Dermatol. 1981, 117:65053.

31. Moy RL, Luftman DB, Nguyen QH, Amenta JS: Estrogen receptors and the response to sex hormones in angiolymphoid hyperplasia with eosinophilia. Arch Dermatol. 1992, 128:825-8.

32. Huang SC, Zhang L, Sung YS, et al.: Frequent FOS gene rearrangements in epithelioid hemangioma. A molecular study of 58 cases with morphologic reappraisal. Am J Surg Pathol. 2015, 39:1313-21. 10.1097/PAS.0000000000000469

33. Fetsch JF, Sesterhenn IA, Miettinen M, Davis CJ Jr: Epithelioid hemangioma of the penis: a clinicopathologic and immunohistochemical analysis of 19 cases, with special reference to exuberant examples often confused with epithelioid hemangioendothelioma and epithelioid angiosarcoma. Am J Surg Pathol. 2004, 28:523-33. 10.1097/00000478-200404000-00012

34. Errani C, Zhang L, Sung YS, et al.: A novel WWTR1-CAMTA1 gene fusion is a consistent abnormality in epithelioid hemangioendothelioma of different anatomic sites. Genes Chromosomes Cancer. 2011, 50:64453. 10.1002/gcc.20886

35. Walther C, Tayebwa J, Lilljebjörn H, et al.: A novel SERPINE1-FOSB fusion gene results in transcriptional up-regulation of FOSB in pseudomyogenic haemangioendothelioma. J Pathol. 2014, 232:534-40. 10.1002/path.4322

36. Fletcher C, Unni K, Mertens F, Eds: Epitheloid haemangioma. WHO Classification of Tumors: Pathology and Genetics of Tumors of Soft Tissue and Bones. Fetsch J (ed): IARC Press, Lyon, France; 2000. 159-160.

37. Errani C, Zhang L, Panicek DM, Healey JH, Antonescu CR: Epithelioid hemangioma of bone and soft tissue: a reappraisal of a controversial entity. Clin Orthop Relat Res. 2012, 470:1498-506. 10.1007/s11999-011-20700

38. Deyrup AT, Montag AG: Epithelioid and epithelial neoplasms of bone. Arch Pathol Lab Med. 2007, 131:20516. 10.5858/2007-131-205-EAENOB

39. Keel SB, Rosenberg AE: Hemorrhagic epithelioid and spindle cell hemangioma: a newly recognized, unique vascular tumor of bone. Cancer. 1999, 85:1966-72. 10.1002/(sici)1097-0142(19990501)85:9<1966::aidcncr13>3.0.co;2-w

40. Helander SD, Peters MS, Kuo TT, Daniel Su WP: Kimura's disease and angiolymphoid hyperplasia with eosinophilia: new observations from immunohistochemical studies of lymphocyte markers, endothelial antigens, and granulocyte proteins. J Cutan Pathol. 1995, 22:319-26. 10.1111/j.1600-0560.1995.tb01414.x

41. Ye C, Pan L, Huang Y, et al.: Somatic mutations in exon 17 of the TEK gene in vascular tumors and vascular malformations. J Vasc Surg. 2011, 54:1760-8. 10.1016/j.jvs.2011.06.098

42. Gonzalez-Cuyar LF, Tavora F, Zhao XF, Wang G, Auerbach A, Aguilera N, Burke AP: Angiolymphoid hyperplasia with eosinophilia developing in a patient with history of peripheral T-cell lymphoma: evidence for multicentric T-cell lymphoproliferative process. Diagn Pathol. 2008, 3:22. 10.1186/1746-1596-3-22

43. McKee PH: Pathology of the Skin With Clinical Correlations. Mosby, Elsevier, Maryland Heights, Missouri; 2005.

44. Wells GC, Whimster IW: Subcutaneous angiolymphoid hyperplasia with eosinophilia. Br J Dermatol. 1969, 81:1-15. 10.1111/j.1365-2133.1969.tb15914.x

45. Olsen TG, Helwig EB: Angiolymphoid hyperplasia with eosinophilia. A clinicopathologic study of 116 patients. J Am Acad Dermatol. 1985125, 1:781-796. 10.1016/s0190-9622(85)70098-9

46. Errani C, Sung YS, Zhang L, Healey JH, Antonescu CR: Monoclonality of multifocal epithelioid hemangioendothelioma of the liver by analysis of WWTR1-CAMTA1 breakpoints. Cancer Genet. 2012, 205:12-7. 10.1016/j.cancergen.2011.10.008

47. Righi A, Sbaraglia M, Gambarotti M, et al.: Primary vascular tumors of bone: a monoinstitutional morphologic and molecular analysis of 427 cases with emphasis on epithelioid variants. Am J Surg Pathol. 2020, 44:1192-203. 10.1097/PAS.0000000000001487

48. Antonescu CR, Chen HW, Zhang L, et al.: ZFP36-FOSB fusion defines a subset of epithelioid hemangioma with atypical features. Genes Chromosomes Cancer. 2014, 53:951-9. 10.1002/gcc.22206

49. Kleer CG, Unni KK, McLeod RA: Epithelioid hemangioendothelioma of bone. Am J Surg Pathol. 1996, 20:1301-11. 10.1097/00000478-199611000-00001

50. Rosenberg AE, O’Connell JX, Keel SB, et al.: Epithelioid angiosarcoma of bone. A study of 9 cases . Mod Pathol. 2000, 13:15.

51. Nair M, Aron M, Sharma MC: Angiolymphoid hyperplasia with eosinophilia (epithelioid hemangioma) of the breast: report of a case. Surg Today. 2000, 30:747-9. 10.1007/s005950070090

52. Dey B, Srinivas BH, Badhe B, Nachiappa Ganesh R, Gochhait D, Toi PC, Jinkala S: Malignant epithelioid soft tissue tumours- a pathologist's perspective with review of literature. Cureus. 2020, 12:e12263. 10.7759/cureus.12263

53. Schenker K, Blumer S, Jaramillo D, Treece AL, Bhatia A: Epithelioid hemangioma of bone: radiologic and magnetic resonance imaging characteristics with histopathological correlation. Pediatr Radiol. 2017, 
47:1631-7. 10.1007/s00247-017-3922-x

54. van IJzendoorn DGP, Forghany Z, Liebelt F, et al.: Functional analyses of a human vascular tumor FOS variant identify a novel degradation mechanism and a link to tumorigenesis. J Biol Chem. 2017, 292:2128290. 10.1074/jbc.C117.815845

55. Zaraa I, Mlika M, Chouk S, Chelly I, Mokni M, Zitouna M, Osman AB: Angiolymphoid hyperplasia with eosinophilia: a study of 7 cases. Dermatol Online J. 2011, 17:1.

56. Roh J, Song MJ, Lee MW, Park CS: Solid form of epithelioid hemangioma: a case report . Korean J Pathol. 2014, 48:394-7. 10.4132/KoreanJPathol.2014.48.5.394

57. Cham E, Smoller BR, Lorber DA, Victor TA, Cibull TL: Epithelioid hemangioma (angiolymphoid hyperplasia with eosinophilia) arising on the extremities. J Cutan Pathol. 2010, 37:1045-52. 10.1111/j.16000560.2009.01400.x

58. Weedon D: Skin Pathology Essentials, 2nd Ed. Churchill Livingstone, Edinburgh; 2002. https://books.google.co.in/books? $\mathrm{hl}=$ en \&lr=\&id=NTE_DAAAQBAJ \&oi=fnd \&pg=PP1 \&dq=Skin+Pathology,+2nd+Ed\&ots=VYTwOYx0PR\&sig....

59. Kitamura H, Ito S, Kuwana N, Yutani C: Epithelioid hemangioma of the temporal artery clinically mimicking temporal arteritis. Pathol Int. 1999, 49:831-5. 10.1046/j.1440-1827.1999.00949.x

60. Amin A, Umashankar T, Dsouza CO: Intra-arterial angiolymphoid hyperplasia with eosinophilia: a rare case report of peripheral medium sized muscular artery involvement. J Clin Diagn Res. 2015, 9:ED16-7. 10.7860/JCDR/2015/13044.6327

61. Aurello P, Cicchini C, D'Angelo F, Di Gioia CR, D'Amati G: Angiolymphoid hyperplasia with eosinophilia: a rare artery lesion. Anticancer Res. 2003, 23:3069-72.

62. Grum F, Hufendiek K, Franz S, Bogdahn U, Gamulescu MA, Rümmele P, Schlachetzki F: High-resolution color-coded sonography in angiolymphoid hyperplasia with eosinophilia presenting as temporal arteritis. Circulation. 2010, 121:1045-6. 10.1161/CIR.0b013e3181d38e01

63. Koubaa W, Verdier M, Perez M, Wechsler J: Intra-arterial angiolymphoid hyperplasia with eosinophilia . J Cutan Pathol. 2008, 35:495-8. 10.1111/j.1600-0560.2007.00837.x

64. Sirikulchayanonta V, Jinawath A, Jaovisidha S: Epithelioid hemangioma involving three contiguous bones: a case report with a review of the literature. Korean J Radiol. 2010, 11:692-6. 10.3348/kjr.2010.11.6.692

65. Sin JM, Beck AH, Pai RK, Stevens KJ: Multifocal epithelioid hemangioma with reactive bone formation. Int Sch Res Notices. 2011, 10:378940.

66. Antonescu CR, Le Loarer F, Mosquera JM, et al.: Novel YAP1-TFE3 fusion defines a distinct subset of epithelioid hemangioendothelioma. Genes Chromosomes Cancer. 2013, 52:775-84. 10.1002/gcc.22073

67. Verbeke SL, Bovée JV: Primary vascular tumors of bone: a spectrum of entities? . Int J Clin Exp Pathol. 2011, 4:541-51.

68. Lewis VO, Montag AG, Simon MA: Epithelioid hemangiomas of bone: spontaneous clinical and radiographic remission. Clin Orthop Relat Res. 2003, 167-72.

69. Errani C, Vanel D, Gambarotti M, Alberghini M, Picci P, Faldini C: Vascular bone tumors: a proposal of a classification based on clinicopathological, radiographic and genetic features. Skeletal Radiol. 2012, 41:1495-507. 10.1007/s00256-012-1510-6 